\title{
Inclusion of wheat bran in barley-soybean meal diets with different phosphorus levels for growing-finishing pigs I. Effects on nutrient digestibility and mineral balances in finishing pigs
}

\author{
Euja Helander, MatTI NÄSI and KIrSI PARTANEN
}

\begin{abstract}
Helander, E., NÄsI, M. \& PARTANEN, K. 1994. Inclusion of wheat bran in barley-soybean meal diets with different phosphorus levels for growing-finishing pigs. I. Effects on nutrient digestibility and mineral balances in finishing pigs. Agricultural Science in Finland 3: 27-39. (Department of Animal Science, P.O. Box 28, FIN-00014 University of Helsinki, Finland. Present address: Eija Helander, Cultor Ltd, P.O. Box 105, FIN-00241 Helsinki, Finland.)
\end{abstract}

\begin{abstract}
The effect of the intrinsic phytase of wheat bran (WB) on phytin-phosphorus availability to pigs on barley-soybean meal diets was measured in a digestibility and balance experiment using a $2 \times 3$ factorial arrangement in a $6 \times 5$ cyclic change-over design. The factors were WB inclusion ( 0 or $100 \mathrm{~g}$ per $\mathrm{kg}$, later referred to as WB- and WB+, respectively) and three phosphorus (P) levels: high (HP), medium (MP) and low (LP). The inclusion of WB in the diet did not significantly improve dietary $\mathrm{P}$ utilization. However, the absorption and retention of $\mathrm{P}$ appeared to be slightly improved by WB inclusion in the LP diet. This improvement may be due to WB phytase. The effects of WB on the digestibility and balance of other minerals remained relatively small. The $P$ level, on the other hand, had a greater effect on mineral balances. Ash digestibility was not affected by the treatments. Dry matter and organic matter digestibilities were impaired when WB was included in the diet. $\mathrm{N}$ absorption of intake was higher $(\mathrm{p}<0.01)$ on WB+ diets. The retention of N appeared to decrease on HP and MP diets due to WB, but on LP diets no decrease was observed. Regarding the polluting P-emission, the LPWB+ diet appeared to be the most favourable, since the faecal excretion of $\mathrm{P}$ was the lowest and the overall retention coefficient of $\mathrm{P}$ was the highest. On the basis of these results, an addition of $100 \mathrm{~g} \mathrm{WB}$ to the diet in order to improve $\mathrm{P}$ utilization does not seem very attractive.
\end{abstract}

Key words: phytin, phytase, availability

\section{Introduction}

More than half of the phosphorus (P) in feedstuffs of plant origin occurs in the form of phytate, which is poorly available to non-ruminants (CROMWELL 1992). Phytic acid readily forms complexes with several minerals, like calcium $(\mathrm{Ca})$ and iron $(\mathrm{Fe})$ (HARRIS 1955), zinc ( $\mathrm{Zn}$ ) and manganese (Mn) (ref. ERDMAN 1979) as well as with proteins (SCHEUERMANN et al. 1988a), thus reducing their availability to animals. High levels of phytate in the diet can also cause magnesium $(\mathrm{Mg})$ deficiency (POMERANZ 1978). Pig diets are generally supplemented with inorganic $\mathrm{P}$ to ensure that the $\mathrm{P}$ requirement is satisfied. If the phytate $\mathrm{P}$ of plants could be made more available, a reduction in inorganic $\mathrm{P}$ supplementation of the feeds would be possible, making P-emissions through manure decrease considerably,

Phytase catalyzes the hydrolysis of phytic acid to 
inositol and orthophosphate. The intrinsic phytase activity of different plants varies considerably. Wheat is one of the feedstuffs which has a high phytase activity ranging from 300 to $2000 \mathrm{IU} / \mathrm{kg}$ (1 IU is $1 \mu \mathrm{mol} \mathrm{P}$ liberated from sodium phytate/min at $37^{\circ} \mathrm{C}$ ) (POINTILLART 1988). Most of its phytase appears in the surface layers (POMERANZ 1978). In an experiment by SCHEUERMANN et al. (1988a), wheat phytase was found to hydrolyze maize phytate to the same extent as wheat phytate. BAGHERI and GUEGUEN (1985) have established that the utilization of $\mathrm{P}$ improved when an oats-soybean meal diet was supplemented with $200 \mathrm{~g}$ of wheat bran (WB) per $\mathrm{kg}$. WB addition also improved the utilization of $\mathrm{Mg}$ but decreased that of $\mathrm{Ca}$ and $\mathrm{Zn}$.

The present work was undertaken to evaluate whether the intrinsic phytase of WB could improve the digestibility of phytic P in commercial barleysoybean meal diets enough to serve as a partial or complete replacement for the added inorganic $\mathrm{P}$ in the diets of growing-finishing pigs.

\section{Material and methods}

The digestibility and balance assay was conducted with six Large White $x$ Landrace barrows using a $2 \times 3$ factorial arrangement in a $6 \times 5$ cyclic change- over design. The factors were WB inclusion ( 0 or $100 \mathrm{~g}$ per $\mathrm{kg}$, later referred to as WB- and WB+, respectively) and three $\mathrm{P}$ levels, high (HP), medium (MP) and low (LP) corresponding to $4.33 \mathrm{~g}(3 / 3)$, $2.99 \mathrm{~g}(2 / 3)$ and $1.64 \mathrm{~g} \mathrm{(1/3)}$ digestible P per feed unit ( $\mathrm{FU}=0.7 \mathrm{~kg}$ starch equivalent), respectively. Thus, the experiment consisted of six different diets: HPWB-, HPWB+, MPWB-, MPWB+, LPWB- and LPWB+. The nutrient digestibility, nitrogen $(\mathrm{N})$ balance and the balance of $\mathrm{P}$, calcium $(\mathrm{Ca})$, magnesium $(\mathrm{Mg})$, potassium $(\mathrm{K})$ and zinc $(\mathrm{Zn})$ were determined. The pigs were kept in metabolism cages made of galvanized iron, which allowed separate quantitative collection of faeces and urine. Each period lasted 10 days: five days of adjustment and five days of collection. The initial weight of the pigs was $70.6 \mathrm{~kg}$ (SE 3.57) and the final weight $122.5 \mathrm{~kg}$ (SE 5.52).

The feeds were pelleted $\left(65^{\circ} \mathrm{C}, 4 \mathrm{~mm}\right.$ diameter $)$ barley-soybean meal complete mixtures. The composition of the experimental diets is shown in Table 1. HP diets have been found adequate for pigs with respect to all nutrients (SALO et al. 1990), and the others with respect to all other nutrients except $\mathrm{P}$. The inorganic source of $\mathrm{P}$ in the present experiment was dicalciumphosphate. The energy content was $0.99 \mathrm{FU} / \mathrm{kg}$ in WB- diets and $0.96 \mathrm{FU} / \mathrm{kg}$ in $\mathrm{WB}+$ diets. The intention was to give the same

Table 1. Composition of the experimental diets, $\mathrm{g} / \mathrm{kg}$.

\begin{tabular}{|c|c|c|c|c|c|c|}
\hline Treatment ${ }^{1}$ & HPWB- & HPWB + & MPWB- & MPWB + & LPWB- & LPWB + \\
\hline Barley & 756 & 668 & 759 & 670 & 764 & 674 \\
\hline Soybean meal & 189 & 178 & 188 & 178 & 187 & 178 \\
\hline Wheat bran & - & 100 & - & 100 & - & 100 \\
\hline Molasses & 20 & 20 & 20 & 20 & 20 & 20 \\
\hline Dicalciumphosphate & 16 & 15 & 9 & 8 & 1 & - \\
\hline Limestone & 7 & 7 & 12 & 12 & 16 & 16 \\
\hline Serla Bondex & 5 & 5 & 5 & 5 & 5 & 5 \\
\hline $\mathrm{NaCl}$ & 3 & 3 & 3 & 3 & 3 & 3 \\
\hline Trace mineral mix ${ }^{2}$ & 2 & 2 & 2 & 2 & 2 & 2 \\
\hline Vitamin $\operatorname{mix}^{3}$ & 1 & 1 & 1 & 1 & 1 & 1 \\
\hline Lysine & 1 & 1 & 1 & 1 & 1 & 1 \\
\hline
\end{tabular}

${ }^{1} \mathrm{HP}=$ high $\mathrm{P}, \mathrm{MP}=$ medium $\mathrm{P}, \mathrm{LP}=$ low $\mathrm{P}, \mathrm{WB}-=$ no wheat bran, WB $+=100 \mathrm{~g}$ wheat bran $/ \mathrm{kg}$ diet.

2 Supplied per kg diet: $20 \mathrm{mg} \mathrm{Fe}, 21 \mathrm{mg} \mathrm{Mn}, 21 \mathrm{mg} \mathrm{Cu}, 73 \mathrm{mg} \mathrm{Zn}, 0.2 \mathrm{mg} \mathrm{I}$ and $0.1 \mathrm{mg} \mathrm{Se}$.

${ }^{3}$ Supplied per kg diet: $5000 \mathrm{IU}$ vitamin A, $800 \mathrm{IU}$ vitamin D, $60 \mathrm{mg}$ vitamin E, $2 \mathrm{mg}$ vitamin $\mathrm{K}, 2 \mathrm{mg}$ thiamin, $3 \mathrm{mg}$ riboflavin, $20 \mu \mathrm{g}$ vitamin $\mathrm{B}_{12}, 50 \mu \mathrm{g}$ biotin, $10 \mathrm{mg}$ pantothenic acid and $20 \mathrm{mg}$ niacin. 
amount of FUs/d to each pig (ranging from 2.6 FU to $3.0 \mathrm{FU} / \mathrm{pig} / \mathrm{d}$ in periods 1 to 5 , respectively) but, in practice, the pigs on WB-diets got $0.16 \mathrm{FU} / \mathrm{d}$ more than the other pigs. Just before feeding, the feed was mixed with water (one litre water per $\mathrm{kg}$ feed) and after feeding the pigs were given water $\mathrm{ad}$ libitum.

The feeds and faeces were analyzed by standard methods (AOAC 1984). Amino acids were assayed with a Beckman 6300 amino acid analyzer. ICPAES equipment was used in phytic acid determination (PlaAmi and Kumpulainen 1991). The sample was first burned by inductively coupled plasma and then the P content of the sample was indirectly measured by atomic emission spectrophotometry. $P$ from feeds, water and faeces was analyzed colorimetrically after dry ashing by the vanadomolybdate procedure of TAYSSKY and SHORR (1953). The other minerals of the feeds, drinking water, faeces and urine were measured with a Perkin-Elmer 5100 PC atomic-absorption spectrophotometer, except $\mathrm{K}$, which was assayed with a Corning 435 flame photometer. Phytase activity was measured as free phosphate from phytate after incubating the sample in a $0.1 \mathrm{M}$ sodium acetate buffer, $\mathrm{pH} 5.0$, at $35^{\circ} \mathrm{C}$ for $30 \mathrm{~min}$. A phytase unit (U) is defined as the amount of enzyme that liberates $1 \mu \mathrm{mol}$ of inorganic P from sodium-phytate in one minute. Phytase activity was measured from the main raw materials and from the complete feeds.

The data were subjected to an analysis of variance using the following model (SNEDECOR and COCHRAN 1989):

$Y_{i j k}=\mu+A_{i}+P_{j}+T_{k}+e_{i j k}$

where $\mu=$ overall mean, $\mathrm{A}_{\mathrm{i}}=$ the effect of animal $i$, $\mathrm{P}_{\mathrm{j}}=$ the effect of period $j, \mathrm{~T}_{\mathrm{k}}=$ the effect of treatment $k$ and $\mathrm{e}_{\mathrm{ijk}}=$ residual error.

In analyzing the crude protein digestibility, $\mathrm{N}$ intake was used as a covariate. All other results were first corrected by using FU intake as a covariate, but because it did not have any significant effect on the digestibility and retention of the nutrients, this covariate was omitted. The degrees of freedom for treatment effects were further parti- tioned into single degrees of freedom by the following orthogonal contrasts: $\mathrm{C} 1=\mathrm{WB}-\mathrm{vs} . \mathrm{WB}+, \mathrm{C} 2=$ linear effect of $\mathrm{P}$ level, $\mathrm{C} 3$ = quadratic effect of $\mathrm{P}$ level, $\mathrm{C} 4=$ interaction $\mathrm{C} 1 \times \mathrm{C} 2, \mathrm{C} 5=$ interaction $\mathrm{C} 1$ $x \mathrm{C} 3$.

\section{Results and discussion}

\section{Chemical analyses}

The analyzed chemical composition of the experimental diets is presented in Table 2. Although the experimental feeds were produced in the normal production line of a big feed factory, not designed for mixing small feed batches, the chemical composition of the diets was relatively close to the target. Only the protein and amino acid contents of the diets were sligtly higher than targeted and, therefore, the HPWB+ and MPWB+ diets contained more protein per FU than the other diets. The hemicellulose content varied from $101 \mathrm{~g} / \mathrm{kg} \mathrm{DM}$ to 130 $\mathrm{g} / \mathrm{kg} \mathrm{DM}$, naturally being higher on $\mathrm{WB}+$ diets.

Table 3 shows the $\mathrm{P}, \mathrm{Ca}$ and phytase content of the diets and feed ingredients. The P content of barley was $3.5 \mathrm{~g} / \mathrm{kg} \mathrm{DM}$ and two thirds of it was of phytic origin, which is in accordance with the figures reported earlier by POINTILLART (1988) and JONGBLOED et al. (1991). In WB, 0.89 of total P was of phytic origin. POINTILLART (1988) has reported the corresponding figure to be 0.75 for wheat bran and JONGBLOED et al. (1991) 0.80 for wheat middlings. According to a review by HousEMAN and de BRUYNE (1989), phytate $\mathrm{P}$ is located in the aleurone and pericarp layers in monocotyledons. Thus, the content of phytate $\mathrm{P}$ in wheat bran is highly dependent on the technical process it comes from.

The P contents in HPWB- and HPWB+ diets were 8.2 and $8.0 \mathrm{~g} / \mathrm{kg} \mathrm{DM}$, in MPWB- and MPWB+ diets 6.1 and $6.2 \mathrm{~g} / \mathrm{kg} \mathrm{DM}$, and in LPWBand LPWB+ diets 4.4 and $4.9 \mathrm{~g} / \mathrm{kg} \mathrm{DM}$, respectively. The phytic P content of the experimental diets varied from 0.305 to 0.621 in total $\mathrm{P}$, being always higher on $\mathrm{WB}+$ diets. The digestible $\mathrm{P}$ content of the diets was calculated by using the determined digestibility coefficients (Table 6). Digest- 
Table 2. Chemical composition $(\mathrm{g} / \mathrm{kg} \mathrm{DM})$ and calculated energy content of the experimental diets.

\begin{tabular}{lrrrrrr}
\hline Treatment ${ }^{1}$ & HPWB- & HPWB + & MPWB- & MPWB + & LPWB- & LPWB + \\
\hline Dry matter & 897 & 893 & 896 & 891 & 891 & 900 \\
Ash & 61 & 64 & 61 & 62 & 55 & 54 \\
Crude protein & 199 & 199 & 204 & 202 & 201 & 196 \\
Crude fat & 26 & 28 & 21 & 24 & 24 & 30 \\
Crude fibre & 53 & 53 & 49 & 55 & 56 & 58 \\
Nitrogen free extract & 661 & 656 & 665 & 657 & 664 & 662 \\
Hemicellulose & 104 & 130 & 101 & 114 & 124 & 128 \\
Cellulose & 54 & 48 & 51 & 49 & 50 & 52 \\
Lysine & 10.2 & 10.1 & 11.5 & 10.5 & 10.7 & 11.1 \\
Threonine & 7.2 & 7.1 & 7.4 & 7.1 & 7.0 & 6.8 \\
FU 2 /kg feed & 0.99 & 0.96 & 0.99 & 0.96 & 0.99 & 0.96 \\
ME MJ/kg feed & 12.4 & 12.0 & 12.4 & 12.0 & 12.4 & 12.0 \\
\hline
\end{tabular}

${ }^{1} \mathrm{HP}=$ high phosphorus $(\mathrm{P}), \mathrm{MP}=$ medium $\mathrm{P}, \mathrm{LP}=$ low $\mathrm{P}, \mathrm{WB}-=$ no wheat bran, $\mathrm{WB}+=100 \mathrm{~g}$ wheat bran $/ \mathrm{kg}$ diet.

${ }^{2} \mathrm{FU}=0.7 \mathrm{~kg}$ starch equivalent.

Table 3. Phosphorus, calcium and phytase contents of the experimental diets and feed ingredients ( $\mathrm{g} / \mathrm{kg} \mathrm{DM})$

\begin{tabular}{|c|c|c|c|c|c|c|c|c|c|}
\hline Treatment ${ }^{1}$ & HPWB- & HPWB + & MPWB- & MPWB + & LPWB- & LPWB + & $\begin{array}{c}\text { Soybean } \\
\text { meal }\end{array}$ & Barley & $\begin{array}{c}\text { Wheat } \\
\text { bran }\end{array}$ \\
\hline Phosphorus & 8.2 & 8.0 & 6.1 & 6.2 & 4.4 & 4.9 & 6.8 & 3.5 & 11.3 \\
\hline Phytic acid & 9.0 & 11.0 & 9.3 & 10.9 & 8.8 & 10.7 & 14.4 & 8.2 & 35.6 \\
\hline P from phytic acid & 2.5 & 3.1 & 2.6 & 3.1 & 2.5 & 3.0 & 4.0 & 2.3 & 10.0 \\
\hline Phytic P $\%$ of total P & 0.305 & 0.388 & 0.426 & 0.496 & 0.560 & 0.621 & 0.590 & 0.657 & 0.891 \\
\hline Phytase, U/kg & $<600$ & $<700$ & $<300$ & $<400$ & $<300$ & $<500$ & n.d. ${ }^{2}$ & 300 & 2800 \\
\hline Digestible P (measured) & 4.2 & 4.2 & 2.7 & 2.5 & 1.4 & 1.8 & & & \\
\hline Calcium & 9.9 & 9.7 & 10.5 & 10.0 & 10.4 & 10.7 & & & \\
\hline Digestible Ca & 3.51 & 3.22 & 3.66 & 3.39 & 3.48 & 3.77 & & & \\
\hline $\mathrm{Ca}: \mathrm{P}$ ratio & 1.21 & 1.21 & 1.72 & 1.62 & 2.35 & 2.20 & & & \\
\hline Ca:dig.P ratio & 2.36 & 2.31 & 3.89 & 4.0 & 7.43 & 5.94 & & & \\
\hline Dig.Ca:dig.P ratio & 0.84 & 0.77 & 1.36 & 1.36 & 2.49 & 2.09 & & & \\
\hline
\end{tabular}

$1 \mathrm{HP}=$ high phosphorus $(\mathrm{P}), \mathrm{MP}=$ medium $\mathrm{P}, \mathrm{LP}=$ low $\mathrm{P}, \mathrm{WB}-=$ no wheat bran, $\mathrm{WB}+=100 \mathrm{~g}$ wheat bran $/ \mathrm{kg} \mathrm{diet}$. 2 n.d. $=$ not detected.

ible P ranged from 4.2 to $1.4 \mathrm{~g} / \mathrm{kg} \mathrm{DM}$. On a LPWB+ diet, the measured digestible $\mathrm{P}$ content was $0.4 \mathrm{~g} / \mathrm{kg}$ DM $(28 \%)$ higher than on a LPWBdiet. This difference cannot be explained by the differences in the total $\mathrm{P}$ content of the diets, although the LPWB+ diet contained $11 \%$ more $\mathrm{P}$ than the LPWB- diet. The difference may rather be attributed to WB phytase.

The phytase activity of WB was $2800 \mathrm{U} / \mathrm{kg}$. POINTILLART (1988) has measured activities between 600 and $1700 \mathrm{IU} / \mathrm{kg}$ for wheat bran. The highest enzyme activities in wheat are found from its surface layers (POMERANZ 1978); thus, the processing technology affects the phytase activity of the end product. The phytase activity of barley was the same as in another experiment by Helander (1993, preliminary results). Soybean meal did not show any phytase activity. COSGROVE and IRVING (1980) have reported phytase activity in soybeans, and BAGHERI and GUEGUEN (1982) have also indicated SBM to have some phytase activity. It is likely that the phytase activity in SBM depends on 
the temperature of the process SBM comes from.

There is some inaccuracy in the figures concerning the phytase activitity of the diets: e.g., $100 \mathrm{~g}$ of WB per kg should have increased the phytase activity of WB+ diets by $280 \mathrm{U} / \mathrm{kg}$. No such increase, however, could be found, which lends support to activity loss during pelleting. Steam pelleting at $80^{\circ} \mathrm{C}$ reduced the phytase activity in an experiment by JONGBLOED and KEMME (1990), and SCHWARZ and SCHÖNER (1991) reported 15-25\% losses in phytase activity when the temperature of the pellets was $70^{\circ} \mathrm{C}$. Since the pelleting temperature in the present trial was lower, this does not explain the smaller-than-expected differences between the treatments. It is probably more a question of an analytical problem: when the phytase activity of the feeds is low, the sensitivity of the analytical method may not be sufficient (Puhakka 1993, personal communication). In any case, the phytase activity was always higher on WB+ diets than on other diets.

\section{Digestibilities and balances}

The average dry matter intake of the pigs was $2526 \mathrm{~g}\left(82 \mathrm{~g} / \mathrm{W}^{0.75}\right)$ on WB- diets and $2435 \mathrm{~g}$ $\left(79 \mathrm{~g} / \mathrm{W}^{0.75}\right)$ on $\mathrm{WB}+$ diets. The difference in daily energy intake was $0.16 \mathrm{FU}$. The pigs on $\mathrm{WB}+$ diets ate on average $38 \mathrm{~g}$ more hemicellulose and $8.6 \mathrm{~g}$ more cellulose per day in spite of their lower total feed intake. WB inclusion was found to impair the dry matter digestibility $(\mathrm{p}<0.001)$ (Table 4$)$. There tended to be an interaction between WB inclusion and $\mathrm{P}$ level in organic matter digestibility: the digestibility decreased linearly on $\mathrm{WB}+$ diets $(\mathrm{p}<0.05)$ when the P level of the diets decreased and tended $(\mathrm{p}<0.1)$ to decrease quadratically on WBdiets. No effect on ash digestibility could be found due to treatments. DiGGS et al. (1965) have reported WB to decrease the metabolizable energy content of a diet. Also, other fibre sources are known to decrease digestibility: the faecal digestibility of organic matter was reduced by the inclusion of $50 \mathrm{~g}$ cellulose or $50 \mathrm{~g}$ of straw meal per $\mathrm{kg}$ diet in an experiment conducted by DEN HARTOG et al. (1988).

The amounts of excreted $\mathrm{N}$ and digested $\mathrm{N}$ were affected by the daily $\mathrm{N}$ intake. Correcting the digested $\mathrm{N}$ by $\mathrm{N}$ intake decreased the digestibility coefficient on all WB- diets and increased it on WB+ diets (Table 5). Since phytic acid readily forms complexes with protein, it was interesting to note that the crude protein digestibility improved significantly $(\mathrm{p}<0.01)$ by WB inclusion. This may be due to the intrinsic phytase of WB as in the experiment by MROZ et al. (1991), where a significant improvement in ileal amino acid digestibility by microbial phytase addition was found. Neither $\mathrm{N}$ excretion in urine nor $\mathrm{N}$ retention was significantly affected by daily $\mathrm{N}$ intake; however, $\mathrm{N}$ excretion in urine was always lower $(\mathrm{p}<0.05)$ on $\mathrm{WB}+$ diets. $\mathrm{N}$ retention tended to be lower on $\mathrm{HPWB}+$ and $\mathrm{MPWB}+$ diets than on corresponding diets without

Table 4. Nutrient digestibilities of the experimental diets.

\begin{tabular}{|c|c|c|c|c|c|c|c|c|c|c|c|c|}
\hline \multirow{2}{*}{$\begin{array}{l}\text { Treatment } \\
\text { Nutrient } \\
\text { digestibility }\end{array}$} & \multicolumn{2}{|c|}{$\mathrm{HP}^{\prime}$} & \multicolumn{2}{|c|}{ MP } & \multicolumn{2}{|c|}{ LP } & \multirow[t]{2}{*}{ SEM } & \multicolumn{5}{|c|}{ Statistical significance ${ }^{2}$} \\
\hline & WB- & WB + & WB- & WB + & WB- & WB + & & $\mathrm{Cl}$ & $\mathrm{C} 2$ & $\mathrm{C} 3$ & $\mathrm{C} 4$ & $\mathrm{C} 5$ \\
\hline Dry matter & 0.830 & 0.826 & 0.836 & 0.816 & 0.828 & 0.814 & 0.0035 & $* * *$ & o & NS & NS & NS \\
\hline Organic matter & 0.850 & 0.846 & 0.856 & 0.837 & 0.848 & 0.834 & 0.0031 & $* * *$ & $*$ & NS & NS & o \\
\hline Ash & 0.506 & 0.505 & 0.499 & 0.488 & 0.501 & 0.481 & 0.0125 & NS & NS & NS & NS & NS \\
\hline Crude protein & 0.831 & 0.865 & 0.814 & 0.850 & 0.837 & 0.858 & 0.0051 & $* *$ & NS & $*$ & o & NS \\
\hline
\end{tabular}


Table 5. Nitrogen balance and protein utilization in pigs fed on the experimental diets.

\begin{tabular}{|c|c|c|c|c|c|c|c|c|c|c|c|c|}
\hline \multirow[t]{2}{*}{ Treatment } & \multicolumn{2}{|c|}{ HP } & \multicolumn{2}{|c|}{ MP } & \multicolumn{2}{|c|}{ LP } & \multirow[t]{2}{*}{ SEM } & \multicolumn{5}{|c|}{ Statistical significance } \\
\hline & WB- & WB + & WB- & $\mathrm{WB}+$ & WB- & WB + & & $\mathrm{Cl}$ & $\mathrm{C} 2$ & $\mathrm{C} 3$ & $\mathrm{C} 4$ & C5 \\
\hline $\mathrm{N}$ intake, $\mathrm{g} / \mathrm{d}$ & 80.6 & 77.7 & 85.2 & 78.2 & 80.7 & 76.5 & 0.41 & $* * *$ & NS & $* * *$ & NS & $* * *$ \\
\hline $\begin{array}{l}\mathrm{N} \text { excretion in } \\
\text { faeces, } \mathrm{g} / \mathrm{d}\end{array}$ & 13.1 & 11.6 & 12.8 & 12.6 & 12.6 & 12.5 & 0.26 & $*$ & NS & NS & $*$ & NS \\
\hline $\mathrm{N}$ digested, $\mathrm{g} / \mathrm{d}$ & 67.5 & 66.1 & 72.4 & 65.6 & 68.0 & 64.0 & 0.59 & $* * *$ & NS & $* * *$ & $*$ & $* *$ \\
\hline -of intake & 0.836 & 0.851 & 0.850 & 0.839 & 0.843 & 0.836 & 0.0040 & NS & NS & NS & $*$ & NS \\
\hline $\begin{array}{l}\text {-of intake } \\
\text { (corrected by } \\
\mathrm{N} \text { intake) }\end{array}$ & 0.831 & 0.865 & 0.814 & 0.850 & 0.837 & 0.858 & 0.0030 & $* *$ & NS & $*$ & o & NS \\
\hline $\begin{array}{l}\mathrm{N} \text { excretion in } \\
\text { urine, } \mathrm{g} / \mathrm{d}\end{array}$ & 31.9 & 32.7 & 37.1 & 33.1 & 36.0 & 31.3 & 1.26 & $*$ & NS & o & $*$ & NS \\
\hline $\mathrm{N}$ retained, $\mathrm{g} / \mathrm{d}$ & 35.6 & 33.4 & 35.3 & 32.4 & 32.0 & 32.6 & 1.16 & NS & o & NS & NS & NS \\
\hline -of intake & 0.446 & 0.432 & 0.417 & 0.418 & 0.400 & 0.428 & 0.0142 & NS & NS & NS & NS & NS \\
\hline - of digested & 0.535 & 0.508 & 0.491 & 0.498 & 0.475 & 0.514 & 0.0174 & NS & NS & NS & o & NS \\
\hline$-\mathrm{g} / \mathrm{W}^{0.75} / \mathrm{d}$ & 1.158 & 1.091 & 1.154 & 1.065 & 1.041 & 1.088 & 0.0377 & NS & NS & NS & NS & NS \\
\hline Urea $\mathrm{N}, \mathrm{g} / \mathrm{d}$ & 24.8 & 27.1 & 28.8 & 27.2 & 30.8 & 27.5 & 1.22 & NS & $*$ & NS & $*$ & NS \\
\hline $\begin{array}{l}\text { Urea N, } \\
\mathrm{g} / \mathrm{W}^{0.75} / \mathrm{d}\end{array}$ & 0.769 & 0.862 & 0.905 & 0.857 & 0.970 & 0.868 & 0.0399 & NS & $*$ & NS & $*$ & NS \\
\hline Biological value & 0.602 & 0.577 & 0.556 & 0.568 & 0.545 & 0.584 & 0.0167 & NS & NS & NS & o & NS \\
\hline
\end{tabular}

WB. No decrease in $\mathrm{N}$ retention due to WB was found on the LP diet. Some interactions between WB inclusion and $\mathrm{P}$ level were found. A decreasing $P$ level had a linear $(\mathrm{p}<0.05)$ and a curvilinear $(\mathrm{p}<0.1)$ increasing effect on $\mathrm{N}$ excretion on WBdiets, while no effect due to $\mathrm{P}$ was found on WB+ diets. A decreasing $\mathrm{P}$ level also seemed to have a linear decreasing effect on $\mathrm{N}$ retention $(\mathrm{p}<0.05)$ and on the biological value of protein $(\mathrm{p}<0.05)$ on WBdiets. On WB+ diets those parameters remained constant. No effect on $\mathrm{N}$ digestibility or $\mathrm{N}$ retention was found in an earlier experiment where the inorganic P was omitted from the diet (NÄSI and HELANDER 1993).

The average daily intake of $\mathrm{P}$ ranged from 20.5 $\mathrm{g} / \mathrm{d}$ on a HPWB+ diet to $12.5 \mathrm{~g} / \mathrm{d}$ on a LPWB- diet (Table 6). The dicalciumphosphate content of the diets varied from $16 \mathrm{~g} / \mathrm{kg}$ in a HPWB- diet to $1 \mathrm{~g} / \mathrm{kg}$ on a LPWB- diet. On LPWB+ diets, all P was of plant origin. Phytic $P$ ranged from 0.305 to 0.560 and from 0.388 to 0.621 of total P in WB- and WB+ diets, respectively. Although the excretion of $\mathrm{P}$ in faeces decreased linearly $(\mathrm{p}<0.01)$ with a decreasing $\mathrm{P}$ content of the diet, the differences in excretion between treatments were not significant. P excretion ranged from $9.88 \mathrm{~g} / \mathrm{d}$ on a HPWB- diet to $8.22 \mathrm{~g} / \mathrm{d}$ on a LPWB+ diet. Also the apparent digestibility of $\mathrm{P}$ (\% of intake), decreased linearly $(\mathrm{p}<0.001)$ with a decreasing $\mathrm{P}$ content of the diet. In the previously mentioned digestibility and balance study conducted by NÄSI and HELANDER (1993), the faecal excretion of $\mathrm{P}$ was about twice as high in diets with inorganic P supplementation as compared to unsupplemented diets. The absorption of $\mathrm{P}$ was then on an equal level (3.8-3.9 g/d) with $\mathrm{P}$ absorption on the LPWB- diet $(4.0 \mathrm{~g} / \mathrm{d})$ in this study, although the daily intake of $\mathrm{P}$ in the present experiment was one-third higher. A possible reason for the low absorption rate of $\mathrm{P}$ in the present experiment may be related to the age of the pigs. In 
Table 6. Excretion, apparent digestibility and retention of phosphorus in pigs fed on the experimental diets.

\begin{tabular}{|c|c|c|c|c|c|c|c|c|c|c|c|c|}
\hline \multirow[t]{2}{*}{ Treatment } & \multicolumn{2}{|c|}{ HP } & \multicolumn{2}{|c|}{ MP } & \multicolumn{2}{|c|}{ LP } & \multirow[t]{2}{*}{ SEM } & \multicolumn{5}{|c|}{ Statistical significance } \\
\hline & WB- & WB + & WB- & WB + & WB- & WB + & & $\mathrm{Cl}$ & $\mathrm{C} 2$ & $\mathrm{C} 3$ & $\mathrm{C} 4$ & $\mathrm{C} 5$ \\
\hline$P$ intake, $g / d$ & 20.32 & 20.51 & 16.45 & 15.82 & 12.50 & 12.96 & 0.136 & NS & *** & $* *$ & NS & ** \\
\hline $\begin{array}{l}\text { P excretion } \\
\text { in faeces } g / d\end{array}$ & 9.88 & 9.75 & 9.20 & 9.33 & 8.51 & 8.22 & 0.461 & NS & $* *$ & NS & NS & NS \\
\hline$P$ digested, g/d & $\begin{array}{r}9.00 \\
10.44\end{array}$ & 10.76 & $\begin{array}{l}7.20 \\
7.24\end{array}$ & $\begin{array}{l}9.33 \\
6.48\end{array}$ & $\begin{array}{l}0.51 \\
3.99\end{array}$ & $\begin{array}{l}0.22 \\
4.74\end{array}$ & 0.401 & NS & *** & NS & NS & NS \\
\hline P digestibility & 0.514 & 0.528 & 0.442 & 0.408 & 0.322 & 0.369 & 0.0286 & NS & $* * *$ & NS & NS & NS \\
\hline $\begin{array}{l}\text { Urinary } \mathrm{P} \\
\text { excretion, g/d }\end{array}$ & 3.99 & 3.94 & 2.06 & 1.82 & 0.39 & 0.23 & 0.164 & NS & $* * *$ & NS & NS & NS \\
\hline$P$ retained, $g / d$ & 6.45 & 6.82 & 5.19 & 4.67 & 3.59 & 4.51 & 0.503 & NS & $* * *$ & NS & NS & NS \\
\hline -of intake & 0.318 & 0.334 & 0.318 & 0.294 & 0.291 & 0.350 & 0.0305 & NS & NS & NS & NS & NS \\
\hline -of digested & 0.621 & 0.620 & 0.718 & 0.724 & 0.875 & 0.946 & 0.0272 & NS & $* * *$ & NS & NS & NS \\
\hline$-\mathrm{g} / \mathrm{W}^{0,75}$ & 0.208 & 0.218 & 0.168 & 0.152 & 0.117 & 0.149 & 0.0147 & NS & $* * *$ & NS & NS & NS \\
\hline
\end{tabular}

$1 \mathrm{HP}=$ high phosphorus $(\mathrm{P}), \mathrm{MP}=$ medium $\mathrm{P}, \mathrm{LP}=$ low $\mathrm{P}, \mathrm{WB}-=$ no wheat bran, $\mathrm{WB}+=100 \mathrm{~g}$ wheat bran $/ \mathrm{kg}$ diet.

$2(\mathrm{P}<0.10) 0,(\mathrm{P}<0.05)^{*},(\mathrm{P}<0.01)^{* *},(\mathrm{P}<0.001)^{* * *},(\mathrm{P}>0.10) \mathrm{NS}$

$\mathrm{C} 1=\mathrm{WB}-\mathrm{vs}$. WB,$+ \mathrm{C} 2=\mathrm{P}$ lin, $\mathrm{C} 3=\mathrm{P}$ quadr, $\mathrm{C} 4=\mathrm{C} 1 \times \mathrm{C} 2, \mathrm{C} 5=\mathrm{C} 1 \times \mathrm{C} 3$

the earlier study, the pigs were younger and, thus, weighed less (weight $36-88 \mathrm{~kg}$ ) than the pigs in this study (71-122 kg). JONGBLOED (1987) reviewed the adaptation of young animals to widely differing amounts of $\mathrm{P}$ and $\mathrm{Ca}$ in the diet by varying their intestinal absorption, and found that a decrease in the adaptation of the intestine to dietary $\mathrm{P}$ and $\mathrm{Ca}$ restriction occurs with increasing age. This is supporied by the findings of NÄSI (1990): in older pigs the retention of $\mathrm{P}$ remained low in spite of a high $\mathrm{P}$ supply on a maize-soybean meal diet. Another explanation for the lower absorption rate of $\mathrm{P}$ on a LPWB- diet as compared to the earlier results may be the less favourable $\mathrm{Ca}: \mathrm{P}$ ratio in this experiments (2.3 vs 1.8). A wide $\mathrm{Ca}: \mathrm{P}$ ratio has an important negative influence on a low-phosphorus diet (De WILDE and JOURQUIN 1992). JONGBLOED (1987) concluded in his trials that the higher the $\mathrm{Ca}$ content of the diet, the more the absorption percentage of $\mathrm{P}$ and $\mathrm{Ca}$ decreased at increasing live weights.

Phosphorus homeostasis appears to be achieved mainly by regulating excretion via urine (LINDER 1991). When the P supply in the diet is low, the animal tries to retain the plasma $\mathrm{P}$ level constant by reabsorbing $\mathrm{P}$ from the kidneys. In the present study, the urinary $\mathrm{P}$ excretion decreased linearly $(\mathrm{p}<0.001)$ with a decreasing $\mathrm{P}$ content of the diet. The proportion of absorbed $\mathrm{P}$ that was retained increased linearly $(\mathrm{p}<0.001)$ when the $P$ content of the diet decreased, ranging from 0.620 on a HPWB+ diet to 0.946 on a LPWB+ diet. This is in agreement with earlier observations (NÄSI 1990, NÄSI and HELANDER 1993).

The inclusion of WB in the diet did not improve the digestibility of P. However, the amount of $\mathrm{P}$ excreted in urine was non-significantly lower on $\mathrm{WB}+$ diets. The absorption of $\mathrm{P}$ appeared to be 0.75 $\mathrm{g} / \mathrm{d}(18.8 \%)$ higher on the LPWB+ diet compared to the LPWB- diet. The proportion of absorbed $\mathrm{P}$ that was retained was 7.1 percentage units, i.e. almost 1 $\mathrm{g} / \mathrm{d}$ higher on the LPWB+ diet than on the LPWBdiet. The P intake was $0.5 \mathrm{~g} / \mathrm{d}$ higher on a LPWBdiet, but this hardly explains the differences in absorption and retention. Thus, it can be assumed that WB (phytase) had improved the utilization of phytic $\mathrm{P}$ on the low-P diet. The apparent $\mathrm{P}$ absorption was found to improve by $21 \%$ in a study by NEWTON et al. (1983), when a corn-soybean meal diet with a normal P level was supplemented with $100 \mathrm{~g} \mathrm{WB}$. Those results are, however, not fully 
Table 7. Calcium excretion, apparent digestibility and retention in pigs fed on the experimental diets.

\begin{tabular}{|c|c|c|c|c|c|c|c|c|c|c|c|c|}
\hline \multirow[t]{2}{*}{ Treatment } & \multicolumn{2}{|c|}{ HP } & \multicolumn{2}{|c|}{ MP } & \multicolumn{2}{|c|}{ LP } & \multirow[t]{2}{*}{ SEM } & \multicolumn{5}{|c|}{ Statistical significance } \\
\hline & WB- & WB + & WB- & WB + & WB- & $\mathrm{WB}+$ & & $\mathrm{Cl}$ & $\mathrm{C} 2$ & $\mathrm{C} 3$ & $\mathrm{C} 4$ & C5 \\
\hline $\mathrm{Ca}$ intake, $\mathrm{g} / \mathrm{d}$ & 22.11 & 22.41 & 23.08 & 22.08 & 22.85 & 22.44 & 0.118 & ** & ** & NS & ** & $* * *$ \\
\hline $\begin{array}{l}\text { Ca supply in } \\
\text { water, } g / d\end{array}$ & 0.11 & 0.11 & 0.12 & 0.11 & 0.12 & 0.11 & 0.005 & NS & NS & NS & NS & NS \\
\hline $\begin{array}{l}\text { Ca excretion } \\
\text { in faeces, } \mathrm{g} / \mathrm{d}\end{array}$ & 14.34 & 15.05 & 15.10 & 14.66 & 15.30 & 14.66 & 0.546 & NS & NS & NS & NS & NS \\
\hline $\begin{array}{l}\text { Ca absorption, } \\
g / d\end{array}$ & 7.88 & 7.47 & 8.10 & 7.53 & 7.67 & 7.89 & 0.530 & NS & NS & NS & NS & NS \\
\hline $\mathrm{Ca}$ absorption & 0.355 & 0.332 & 0.349 & 0.339 & 0.335 & 0.352 & 0.0240 & NS & NS & NS & NS & NS \\
\hline $\begin{array}{l}\text { Urinary Ca } \\
\text { excretion, g/d }\end{array}$ & 0.44 & 0.43 & 0.48 & 0.35 & 0.87 & 1.04 & 0.139 & NS & ** & $*$ & NS & NS \\
\hline $\begin{array}{l}\text { Ca retained, } \\
\mathrm{g} / \mathrm{d}\end{array}$ & 7.44 & 7.03 & 7.62 & 7.18 & 6.81 & 6.84 & 0.568 & NS & NS & NS & NS & NS \\
\hline -of intake & 0.335 & 0.312 & 0.328 & 0.324 & 0.296 & 0.304 & 0.0258 & NS & NS & NS & NS & NS \\
\hline -of absorption & 0.943 & 0.946 & 0.942 & 0.955 & 0.893 & 0.866 & 0.0199 & NS & ** & NS & NS & NS \\
\hline$-\mathrm{g} / \mathrm{W}^{0,75}$ & 0.238 & 0.227 & 0.245 & 0.232 & 0.217 & 0.223 & 0.019 & NS & NS & NS & NS & NS \\
\hline
\end{tabular}

' $\mathrm{HP}=$ high phosphorus $(\mathrm{P}), \mathrm{MP}=$ medium $\mathrm{P}, \mathrm{LP}=$ low $\mathrm{P}, \mathrm{WB}-=$ no wheat bran, $\mathrm{WB}+=100 \mathrm{~g}$ wheat bran $/ \mathrm{kg}$ diet.

${ }^{2}(\mathrm{P}<0.10)$ o, $(\mathrm{P}<0.05)^{*},(\mathrm{P}<0.01)^{* *},(\mathrm{P}<0.001)^{* * *},(\mathrm{P}>0.10)$ NS

$\mathrm{C} 1=\mathrm{WB}-$ vs. $\mathrm{WB}+, \mathrm{C} 2=\mathrm{P}$ lin, $\mathrm{C} 3=\mathrm{P}$ quadr, $\mathrm{C} 4=\mathrm{C} 1 \times \mathrm{C} 2, \mathrm{C} 5=\mathrm{C} 1 \times \mathrm{C} 3$

comparable with ours, because WB inclusion also enhanced the total P intake. POINTILlaRT (1991) reported that $\mathrm{P}$ from a diet to which no inorganic $\mathrm{P}$ was added and which was supplemented by $20 \%$ of rye bran, was better absorbed (55 vs $36 \%$ ) and retained ( 50 vs $36 \%$ ) by pigs of $12-43 \mathrm{~kg}$ live weight than $\mathrm{P}$ from the control diet.

The $\mathrm{Ca}$ intake of the pigs ranged between 22-23 $\mathrm{g} / \mathrm{d}$ (Table 7). Ca digestibility was not affected by WB inclusion or by decreasing the P content of the diet, whereas urinary $\mathrm{Ca}$ excretion increased linearly $(\mathrm{p}<0.01)$ and quadratically $(\mathrm{p}<0.05)$ with a decreasing dietary $\mathrm{P}$ content. The results of the present study show that $\mathrm{Ca}$ balance is mainly regulated through the intestine as was also concluded by FERNÁNDEZ (1992). In an experiment by DEN HARTOG et al. (1988) apparent faecal digestibility of Ca decreased, when the diet was supplemented with 50 g pectin, cellulose or straw meal per kg. No significant differences were found in Ca retention due to treatments. However, the retention tended to be lower on LP than on other diets. JONGBLOED (1987) reported the daily Ca retention to vary from 6 to $8 \mathrm{~g}$ after $55 \mathrm{~kg}$ live weight, which is well in accordance with our results. The proportion of digested $\mathrm{Ca}$ that was retained decreased linearly $(\mathrm{p}<0.01)$ when the $\mathrm{P}$ content of the diet decreased. In our previous digestibility and balance study (NÄSI and HELANDER 1993), Ca absorption was lower in a P-supplemented diet compared to an unsupplemented diet, but no significant differences were found in Ca retention because the urinary Ca excretion was also lower. POINTILLART (1991) reported no change in Ca absorption ( 53 vs. $50 \%$ ) but higher Ca retention ( 52 vs. $45 \%$ ) on a diet with 200 $\mathrm{g}$ inclusion of rye bran per $\mathrm{kg}$ feed than on a diet without any inorganic $\mathrm{P}$ supplement.

$\mathrm{Mg}$ intake was higher $(\mathrm{p}<0.001)$ on $\mathrm{WB}+$ diets and decreased when the dietary $\mathrm{P}$ level decreased $(\mathrm{p}<0.001)$ (Table 8). This indicates that both WB and dicalciumphosphate have contributed some $\mathrm{Mg}$ to the diet. Daily Mg absorption did not differ between treatments. According to LINDER (1991), dietary $\mathrm{Ca}$ and $\mathrm{P}$ do not affect the absorption of $\mathrm{Mg}$ 
Table 8. Magnesium excretion, apparent digestibility and retention in pigs fed on the experimental diets.

\begin{tabular}{|c|c|c|c|c|c|c|c|c|c|c|c|c|}
\hline \multirow[t]{2}{*}{ Treatment } & \multicolumn{2}{|c|}{ HP } & \multicolumn{2}{|c|}{ MP } & \multicolumn{2}{|c|}{ LP } & \multirow[t]{2}{*}{ SEM } & \multicolumn{5}{|c|}{ Statistical significance } \\
\hline & WB- & WB + & WB- & WB + & WB- & WB + & & $\mathrm{Cl}$ & $\mathrm{C} 2$ & C3 & $\mathrm{C} 4$ & C5 \\
\hline $\mathrm{Mg}$ intake, $\mathrm{g} / \mathrm{d}$ & 5.09 & 5.58 & 5.25 & 5.41 & 4.71 & 5.15 & 0.028 & $* * *$ & $* * *$ & $* * *$ & NS & $* * *$ \\
\hline $\begin{array}{l}\text { Mg supply in } \\
\text { water, g/d }\end{array}$ & 0.50 & 0.50 & 0.56 & 0.50 & 0.55 & 0.52 & 0.022 & NS & NS & NS & NS & NS \\
\hline $\begin{array}{l}\text { Mg excretion } \\
\text { in faeces, } g / d\end{array}$ & 3.56 & 3.80 & 3.58 & 3.87 & 3.54 & 3.59 & 0.107 & * & NS & NS & NS & NS \\
\hline $\begin{array}{l}\text { Mg absorption, } \\
\mathrm{g} / \mathrm{d}\end{array}$ & 2.03 & 2.28 & 2.22 & 2.04 & 1.72 & 2.08 & 0.109 & NS & $*$ & NS & NS & $*$ \\
\hline Mg absorption & 0.361 & 0.374 & 0.382 & 0.344 & 0.327 & 0.367 & 0.0186 & NS & NS & NS & NS & NS \\
\hline $\begin{array}{l}\text { Urinary } \mathrm{Mg} \\
\text { excretion, g/d }\end{array}$ & 0.66 & 0.66 & 0.70 & 0.72 & 0.87 & 0.88 & 0.040 & NS & $* * *$ & NS & NS & NS \\
\hline $\begin{array}{l}\text { Mg retained, } \\
g / d\end{array}$ & 1.37 & 1.62 & 1.52 & 1.32 & 0.85 & 1.19 & 0.127 & NS & $* *$ & NS & NS & $*$ \\
\hline -of intake & 0.243 & 0.246 & 0.261 & 0.223 & 0.163 & 0.212 & 0.0227 & NS & ** & NS & NS & NS \\
\hline -of absorption & 0.673 & 0.704 & 0.684 & 0.644 & 0.464 & 0.573 & 0.0431 & NS & $* *$ & NS & NS & NS \\
\hline$-\mathrm{g} / \mathrm{W}^{0,75}$ & 0.044 & 0.051 & 0.049 & 0.042 & 0.028 & 0.039 & 0.0038 & NS & $* *$ & NS & NS & $*$ \\
\hline
\end{tabular}

in humans (the studies have, however, usually been done with animals). $\mathrm{Mg}$ homeostasis occurs similarly as with $\mathrm{P}$, and thus, mainly via adjustments of urinary excretion in humans (LINDER 1991). According to CRENSHAW (1991) the regulation of body $\mathrm{Mg}$ levels in pigs is not very well understood. In a study by NEWTON et al. (1983) WB inclusion was not found to affect the apparent digestibility of Mg in pigs in a study by NEWTON et al. (1983). In the present experiment, $\mathrm{Mg}$ excretion in urine increased $(\mathrm{p}<0.001)$ with a lower dietary P content. An interaction between WB inclusion and $\mathrm{P}$ level was recorded in $\mathrm{Mg}$ retention: on $\mathrm{WB}+$ diets $\mathrm{Mg}$ retention decreased linearly $(\mathrm{p}<0.05)$ and on WBdiets both linearly $(\mathrm{p}<0.05)$ and curvilinearly $(\mathrm{p}<0.05)$ with a decreasing $\mathrm{P}$ content. These results contradict those of a study by NÄSI (1990), in which $\mathrm{Mg}$ absorption improved and retention remained unchanged on a unsupplemented maize-soybean meal diet compared with a diet supplemented by inorganic P. The results are, however, well in accordance with those of an earlier study by NÄSI and
HELANDER (1993), where barley-soybean meal diets were used.

$\mathrm{K}$ digestibility was not affected by WB inclusion (Table 9). This result is in conflict with the results of NEWTON et al. (1983), who reported that the apparent absorption of $\mathrm{K}$ decreased significantly when the diet was supplemented by $100 \mathrm{~g}$ of $\mathrm{WB} / \mathrm{kg}$ and non-significantly when supplemented by $200 \mathrm{~g}$ of WB/kg. Urinary K excretion was increased slightly when WB was included in the diet. In $\mathrm{K}$ retention, an interaction was observed between WB and P level: on WB- diets the retention decreased curvilinearly $(\mathrm{p}<0.05)$ while on $\mathrm{WB}+$ diets the retention remained constant when the $\mathrm{P}$ level of the diet decreased.

Due to unknown reasons there was a large variation in zinc $(\mathrm{Zn})$ intake between treatments (Table 9). A high $\mathrm{Zn}$ intake led to a higher $\mathrm{Zn}$ excretion in faeces. The daily $\mathrm{Zn}$ absorption and retention were the highest on MPWB- and MPWB+ diets and were unaffected by WB inclusion. In retention, again, an interaction was found between 
Table 9. Apparent digestibility and retention of potassium and zinc in pigs fed on the experimental diets.

\begin{tabular}{|c|c|c|c|c|c|c|c|c|c|c|c|c|}
\hline \multirow[t]{2}{*}{ Treatment } & \multicolumn{2}{|c|}{ HPI $^{\prime}$} & \multicolumn{2}{|c|}{ MP } & \multicolumn{2}{|c|}{ LP } & \multirow[t]{2}{*}{ SEM } & \multicolumn{5}{|c|}{ Statistical significance 2} \\
\hline & WB- & WB + & WB- & WB + & WB- & WB + & & $\mathrm{Cl}$ & $\mathrm{C} 2$ & $\mathrm{C} 3$ & $\mathrm{C} 4$ & C5 \\
\hline \multicolumn{13}{|l|}{ Potassium } \\
\hline Intake, g/d & 24.70 & 25.79 & 27.19 & 26.07 & 25.26 & 26.67 & 0.399 & NS & NS & ** & NS & ** \\
\hline Digested & 0.766 & 0.774 & 0.808 & 0.768 & 0.803 & 0.804 & 0.0138 & NS & $*$ & NS & NS & NS \\
\hline $\begin{array}{l}\text { Excretion in } \\
\text { urine, } \mathrm{g} / \mathrm{d}\end{array}$ & 15.86 & 15.38 & 16.93 & 15.98 & 17.35 & 17.52 & 0.235 & * & $* * *$ & NS & NS & NS \\
\hline Retention, g/d & 3.07 & 4.60 & 5.04 & 4.02 & 2.92 & 3.94 & 0.578 & NS & NS & NS & NS & $*$ \\
\hline -of intake & 0.127 & 0.175 & 0.187 & 0.156 & 0.117 & 0.148 & 0.0212 & NS & NS & o & NS & NS \\
\hline -of digested & 0.163 & 0.224 & 0.229 & 0.202 & 0.144 & 0.183 & 0.0250 & NS & NS & NS & NS & NS \\
\hline Zine & & & & & & & & & & & & \\
\hline Intake, mg/d & 274 & 276 & 394 & 373 & 255 & 357 & 2.1 & $* * *$ & $* * *$ & $* * *$ & $* * *$ & *** \\
\hline Digested & 0.296 & 0.215 & 0.357 & 0.343 & 0.233 & 0.270 & 0.0352 & NS & NS & $* *$ & NS & NS \\
\hline $\begin{array}{l}\text { Excretion in } \\
\text { urine, } \mathrm{mg} / \mathrm{d}\end{array}$ & 6.0 & 6.2 & 11.8 & 8.7 & 10.1 & 11.2 & 1.27 & NS & $* *$ & NS & NS & NS \\
\hline Retention, mg/d & 75 & 54 & 129 & 121 & 49 & 85 & 9.95 & NS & NS & $* * *$ & $*$ & NS \\
\hline -of intake & 0.274 & 0.193 & 0.327 & 0.319 & 0.193 & 0.238 & 0.0358 & NS & NS & $* *$ & NS & NS \\
\hline -of digested & 0.924 & 0.978 & 0.915 & 0.939 & 0.820 & 0.877 & 0.0240 & $*$ & $* * *$ & NS & NS & NS \\
\hline
\end{tabular}

${ }^{1} \mathrm{HP}=$ high phosphorus $(\mathrm{P}), \mathrm{MP}=$ medium $\mathrm{P}, \mathrm{LP}=$ low $\mathrm{P}, \mathrm{WB}-=$ no wheat bran, $\mathrm{WB}+=100 \mathrm{~g}$ wheat bran $/ \mathrm{kg}$ diet.

$2(\mathrm{P}<0.10)$ o, $(\mathrm{P}<0.05)^{*},(\mathrm{P}<0.01)^{* *},(\mathrm{P}<0.001)^{* * *},(\mathrm{P}>0.10) \mathrm{NS}$

$\mathrm{C} 1=\mathrm{WB}-$ vs. WB,$+ \mathrm{C} 2=\mathrm{P}$ lin, $\mathrm{C} 3=\mathrm{P}$ quadr, $\mathrm{C} 4=\mathrm{C} 1 \times \mathrm{C} 2, \mathrm{C} 5=\mathrm{C} 1 \times \mathrm{C} 3$

WB inclusion and $\mathrm{P}$ level: on $\mathrm{WB}+$ diets $\mathrm{Zn}$ retention increased linearly $(\mathrm{p}<0.05)$ and quadratically $(\mathrm{p}<0.001)$ and on WB- diets it decreased quadratically $(\mathrm{p}<0.001)$ with a decreasing dietary $\mathrm{P}$ level. In a study by NÄSI (1990) Zn absorption and retention were higher in diets without phosphate addition, but remained unaffected in a later study by NÄSI and HELANDER (1993). The proportion of digested $\mathrm{Zn}$ that was retained was higher on all $\mathrm{WB}+$ diets than on WB-diets. In a trial made by NEWTON et al. (1983) $\mathrm{Zn}$ apparent absorption decreased, when the WB level of the diet increased. The indigestible, fibrous bran fraction was found to accumulate some minerals such as $\mathrm{Zn}$. Unfortunately, the retention of minerals was not determined in that study.

The rather low effect of WB phytase on the digestibility of $\mathrm{P}$ and other minerals may be due to several reasons. The optimum temperature for wheat phytase, $55^{\circ} \mathrm{C}$, is higher than the animal body temperature and the optimum $\mathrm{pH}$ for its activity is 5.15 (POMERANZ 1978). For pigs, the stomach seems to be the principal place for the hydrolysis of phytate to utilizable P (JONGBLOED 1987). The low $\mathrm{pH}$ of the stomach can cause the inactivation of plant phytase. The solubility of wheat phytate has been reported to be lowest within the $\mathrm{pH}$ range from 1.5 to 2.5 (SCHEUERMANN et al. 1988a). According to SCHEUERMANN et al. (1988b), pepsin also inhibits the activity of wheat phytase. JONGBLOED (1987) found that an increase in dietary protein level improved the digestibility of P. In the present study, the pigs on $\mathrm{WB}+$ diets ate less protein than the other pigs. This might also explain the low effect of WB on P utilization.

The age of the pigs may also partly explain the results. Older pigs may need less $\mathrm{P}$ in tissue metabolism and/or they are able to utilize phytate $\mathrm{P}$ better (REINHART and MAHAN 1986).

One reason for the poor effect of WB could be that the inclusion of $100 \mathrm{~g} \mathrm{WB}$ used in this experiment per $\mathrm{kg}$ diet may not have been a sufficient amount. The calculated increase in phytase activity 
in the diet was only $280 \mathrm{U} / \mathrm{kg}$. The addition level of microbiologically produced phytase for growingfinishing pigs recommended by BASF (1993) is $500 \mathrm{U}$ per $\mathrm{kg}$ feed, having a total $\mathrm{P}$ content of $4.0-5.0 \mathrm{~g} / \mathrm{kg}$.

The possible decreasing effect of pelleting on enzyme activity was discussed previously. Pelleting may, on the other hand, have a positive effect on the digestibility of P. BAYLEY et al. (1975) have reported improved $\mathrm{P}$ absorption due to steam pelleting. It is interesting to note that such an improvement was found only in diets not supplemented with inorganic $\mathrm{P}$. The pelleting temperature, however, was not mentioned. JONGBLOED (1987) has also reported that the absorption and retention of $\mathrm{P}$ improved with pelleted diets.

In conclusion, the supplementation of a barleysoybean meal diet with $100 \mathrm{~g} \mathrm{WB}$ per $\mathrm{kg}$ was not found to improve the dietary P utilization significantly. However, the digestion and retention of $\mathrm{P}$ appeared to be slightly improved by WB inclusion in the LP diet. This improvement may be due to WB phytase. The effects of WB on the digestibility and balance of other minerals remained relatively small. The P level had a greater effect on mineral balances. The dry matter and organic matter digestibilities were impaired when $100 \mathrm{~g}$ of WB was included in the diet. $\mathrm{N}$ absorption was higher on $\mathrm{WB}+$ diets. The retention of $\mathrm{N}$ appeared to decrease on HP and MP diets due to WB, but no decrease was found on LP diets. Ash digestibility was not affected by the treatments. The LPWB+ diet appeared to be the most favourable regarding the polluting P-emission,, since the faecal excretion of $\mathrm{P}$ on that diet was the lowest and the overall retention coefficient of $\mathrm{P}$ was the highest. This conclusion can, however, be confirmed only after a growth trial. On the basis of the present results, an addition of $100 \mathrm{~g}$ of WB to the diet in order to improve the $\mathrm{P}$ utilization of finishing pigs, does not seem very beneficial.

Acknowledgements. The authors wish to thank Ms. M. Yliaho for technical assistance. The financial support provided by the Academy of Finland and Suomen Rehu Ltd. is gratefully acknowledged.

\section{References}

AOAC 1984. Official methods of analysis. 1141 p. Association of Official Analytical Chemists, Inc., Arlington. Virginia.

BAGHERI, S. 1985. Effect of wheat bran and pectin on the absorption and retention of phosphorus, calcium, magnesium and zinc by the growing pig. Reproduction Nutrition Development 25, 4A: 705-716.

— \& Gueguen, L. 1982. Bioavailability to rats of calcium, magnesium, phosphorus and zinc in wheat bran diets containing equal amounts of these minerals. Nutrition Report International 25: 583-590.

Bayley, H.S., Pos, J. \& Thomson, R.G. 1975. Influence of steam pelleting and dietary calcium level on the utilization of phosphorus by the pig. Journal of Animal Science 40: 857-863.

BASF 1993. Provisional technical leaflet of Natuphos ${ }^{R}$ 5000.4 p.

Cosgrove, D.J. \& Irving, G.C.J. 1980. Inositol phosphates. Their chemistry, biochemistry and physiology. Elsevier. Amsterdam - Oxford - New York. 191 p.

Crenshaw, T.D. 1991. Sodium, potassium, magnesium and chloride in swine nutrition. In: Miller, E.R. et al. (eds.). Swine nutrition. 1th ed., Butterworth-Heinemann, Stoneham, MA, USA. p. 183-191.
Cromwel., G.L. 1992. The biological availability of phosphorus in feedstuffs for pigs. Pig News and Information $13,2: 75 \mathrm{~N}-78 \mathrm{~N}$.

Den Hartog, L.A., Huisman, J., Thielen, W.J.G., Van Schayk, G.H.A., Boer, H. \& Van Weerden, E.J. 1988. The effect of including various structural polysaccharides in pig diets on ileal and faecal digestibility of amino acids and minerals. Livestock Production Science 18: 157-170.

Diggs, B.G., Becker, D.E., Jensen, A.H. \& Norton, H.W. 1965. Energy value of various feeds for the young pig. Journal of Animal Science 24: 555-558.

ERdman, J.W. 1979. Oilseed phytates: Nutritional implications: Journal of the American Oil Chemists Society 56: 736-741.

FERNÁNDEZ, J.A. 1992. Calcium and phosphorus metabolism in growing pigs studied by the balance technique and simultaneous radio-calcium and radio-phosphorus kinetics. The Royal Veterinary and Agricultural University Department of Anatomy and Physiology. Animal Physiology Unit. Thesis. 148 p. Fredriksberg, Denmark.

HarrIS, R.S. 1955. Phytic acid and its importance in human nutrition: Nutrition Reviews 13, 9: 257-259.

Houseman, R.A. \& Bruyne, K. de 1989. PhytinPhosphor und Phytase - Ein Überblick. Kraftfutter 4: 112-115. 
JongBloed, A.W. 1987. Phosphorus in the feeding of pigs. Effect of diet on the absorption and retention of phosphorus by growing pigs. 343 p. I.V.V.O. Rep.No.179. Lelystad, The Netherland.

— , Everts, H. \& Kemme, P.A. 1991. Phosphorus availability and requirements in pigs. In: Haresign, W. \& Cole, D.J.A. (eds.). Recent Advances in Animal Nutrition 1991. Butterworths, London. p. 65-80.

— \& Kemme, P.A. 1990. Effect of pelleting mixed feeds on phytase activity and the apparent absorbability of phosphorus and calcium in pigs. Animal Feed Science and Technology 28: 233-242.

LiNDER, M. C. 1991. Nutrition and metabolism of the major minerals. In: Linder, M. C. (ed.). Nutritional biochemistry and metabolism with clinical applications. p. 191-214. 2th ed. Els. Sci. Publ. Amsterdam.

Mroz, Z., Jongbloed, A.W., Kemme, P.A. \& Lenis, N.P. 1991. Ileal and overall digestibility of nitrogen and amino acids in a diet for pigs as influenced by Aspergillus niger phytase and feeding frequency or levels. In: Eggum, B.O. et al. (eds.). Proceedings of the 6th International Symposium on Protein Metabolism and Nutrition. Herning, Denmark. p. 225-227.

NÄsı, M. 1990. Microbial phytase supplementation for improving availability of plant phosphorus in the diet of the growing pig. Journal of Agricultural Science in Finland 62: 435-443.

— \& Helander, E. 1993. Effects of microbial phytase supplementation and soaking of barley-soybean meal diet for improving availability of plant phosphorus for growing pigs. Acta Agriculturae Scandinavica, Section A., Animal Science 43 (in press).

Nelson, T.S., ShIEH, R.R., Wodinski, R.J. \& WARE, J.H. 1971. Effect of supplemental phytase on the utilization of phytate phosphorus by chicks. Journal of Nutrition 101: 1289-1293.

Newton, G.L., Hale, O.M. \& Plank, C.O. 1983. Effect of wheat bran in practical diets on mineral absorption by pigs at two ages. Canadian Journal of Animal Science 63: 399-408.

Plaami, S. \& Kumpulainen, J. 1991. Determination of phytic acid in cereals using ICP-AES to determine phosphorus. J. Assoc. Off. Anal. Chem. 74: 32-36.

Pointillart, A. 1988. Phytate phosphorus utilization in growing pigs. Proceedings of the 4 th International Seminar on Digestive Physiology in Pigs. Polish Academy of Sciences, Jablonna. p. 319-326.

- 1991. Enhancement of phosphorus utilization in growing pigs fed phytate-rich diets by using rye bran. Journal of Animal Science 69: 1109-1115.

Pomeranz, Y. 1978. Wheat Chemistry and Technology. American Association of cereal chemists, Incorporated. 821 p. 3th Ed., St. Paul, Minnesota. USA.

ReinharT, G.A. \& Mahan, D.C. 1986. Effect of various calcium:phosphorus ratios at low and high dietary phosphorus for starter, grower and finishing swine. Journal of Animal Science 63: 457-466.

SAlo, M.-L., Tuori, M. \& KiISkinen, T. 1990. Rehutaulukot ja ruokintanormit. 70 p. Yliopistopaino, Helsinki.

Scheuermann, S.E., Lantzsch, H.-J. \& Menke, K.H. 1988a. In vitro und in vivo Untersuchungen zur Hydrolyse von Phytat. I. Löslichkeit von Phytat. Journal of Animal Physiology and Animal Nutrition 60: 55-63.

- , Lantzsch, H.-J. \& MenKe, K.H. 1988b. In vitro und in vivo Untersuchungen zur Hydrolyse von Phytat. Aktivität pflanzlicher Phytase. Journal of Animal Physiology and Animal Nutrition 60: 64-75.

Schwarz, G. \& Schöner, F.-J. 1991. Phytase in der Futterung von Schweinen und Geflugel. Kraftfutter 4: 163 168.

Snedecor, G.W. \& Cochran, W.G. 1989. Statistical methods. 503 p. 8th ed. Iowa University Press, Ames, Iowa.

TAYSSKY, H.H. \& SHORR, Е. 1953. A microcolometric method for the determination of inorganic phosphorus. Journal Biological Chemistry 202: 675-685.

WILDE, R.O., de \& JourQuIN, J. 1992. Estimation of digestible phosphorus requirements in growing-finishing pigs by carcass analysis. Journal Animal Physiology and Animal Nutrition 68: 218-225.

Manuscript received September 1993 


\title{
SELOSTUS
}

\section{Vehnäleseen vaikutus kasviperäisen fosforin hyväksikäyttöön lihasian ruokinnassa I. Vaikutus ravintoaineiden sulavuuteen ja kivennäistaseisiin}

\author{
Eua Helander, Matti NÄSI ja Kirsi Partanen
}

Helsingin yliopisto

Sulavuus- ja tasekokeessa tutkittiin, parantaako vehnäleseen fytaasi ohrasta ja soijasta peräisin olevan fosforin hyväksikäyttöä ja voidaanko sillä näin ollen osittain tai kokonaan korvata rehuun normaalisti lisăttävä epäorgaaninen fosfori.

Vehnảlese ei parantanut merkitsevästi fosforin hyväksikäyttöä. Kuitenkin fosforin sulavuus ja pidättyminen paranivat hieman ruokinnalla, jonka fosforitaso oli matala, kun siihen oli lisätty vehnälesettä. Vehnäleseen vaikutus muiden kivennäisten sulavuuteen ja pidăttymiseen jäi văhäiseksi. Fosforitasolla oli kivennäisten sulavuuteen ja pidättymiseen suurempi vaikutus. Tuhkan sulavuus pysyi muuttumattomana eri ruokinnoilla. Kuiva-aineen ja orgaanisen aineen sulavuus heikkenivät vehnäleseen vaikutuksesta. Typen imeytymis-\% oli korkeampi $(\mathrm{p}<0.01)$ vehnălesedieeteillä. Vehnălese näytti alentavan typen pidättymistä korkeimmalla ja keskinkertaisella fosforitasolla, mutta matalalla ei.

Fosforipäästöjä ajatellen matalafosforinen, vehnälesettä sisăltävä ruokinta osoittautui parhaaksi: ulosteiden fosforitaso oli alhaisin ja fosforin pidättymis-\% oli korkein. Tulosten perusteella vehnäleseen käyttö sikojen rehuseoksissa fosforin hyvăkssikäytön parantamiseksi ei kuitenkaan näytä lupaavalta. 